\title{
Результати корекції рогівкового астигматизму при факоемульсифікації катаракти з імп^антацією торичної інтраокулярної ^інзи та за програмою «Біоптика»
}

\begin{abstract}
Резюме. Для оцінки ефективності хірургічного лікування катаракти на очах із рогівковим астигматизмом при факоемульсифікації катаракти з імплантацією торичної інтраокулярної лінзи (IОЛ) та за методом «Біоптика» обстежений 31 хворий (42 ока). Виявлено, що імплантація торичних ІОЛ, як $i$ використання програми «Біоптика», дозволяе досягти високої гостроти зору на очах з астигматизмом. Вірогідне зменшення загального астигматизму мало місце в усіх хворих; віддалені результати більш стабільні при застосуванні програми «Біоптика».
\end{abstract}

Ключові слова: торичні ІОЛ; «Біоптика»; корекція астигматизму

\section{Вступ}

Близько 30 \% населення у світі, як свідчать літературні джерела, мають астигматизм від $0,75 \mathrm{D}$ і вище, що призводить до суб'єктивно відчутного зниження гостроти зору та акомодаційної астенопії [1]. На частку катаракти припадає близько 70 \% всіх випадків внутрішньоочних оперативних втручань. У сучасній хірургії катаракти одним із найбільш актуальних завдань $€$ отримання максимально передбачуваного і точного рефракційного результату [2]. Прагнення хірургів перевести екстракцію катаракти в розряд рефракційних операцій сприяло тому, що на сьогодні золотим рефракційним стандартом є отримання сферичного й астигматичного результату в межах $\pm 0,5 \mathrm{D}$ [3]. Поліпшення рефракційних результатів пов'язано як із удосконаленням хірургічних методик, так і з новими досягненнями в галузі технологій пропонованих методів корекції [4]. У зв'язку з вищевказаним велику увагу стали приділяти вихідному рогівковому астигматизму в хірургії катаракти.

На сучасному етапі одним із запропонованих методів корекції астигматизму є використання торичних ІОЛ [5]. Але, незважаючи на спроби вдосконалення торичних ІОЛ, проблема їх ротації до кінця не вирішена [6].

Для корекції зазначених рефракційних порушень запропоновано різні методи рефракційних операцій. Цілою низкою дослідників було показано, що ексимер- лазерна кераторефракційна операція (Laser-Assisted in Situ Keratomileusis - LASIK) являє собою найбільш сучасний і перспективний напрямок у рефракційній хірургії [7]. Перевагою LASIK є ефективність і більш висока передбачуваність рефракційного ефекту. Застосування ексимерлазерної кераторефракційної операції в комбінації з виконанням факоемульсифікації катаракти здійснюється за програмою «Біоптика». Однак невирішеним є питання терміну виконання ексимерлазерної корекції. За даними літератури, виконання операції коливається від 2 до 6 місяців після факоемульсифікації катаракти. Пояснюється це можливим виникненням ускладнень, пов'язаних із накладенням вакуумного кільця, якщо оперативне лікування виконується біоптичним методом у два етапи. В наш час немає аргументованої єдності рефракційних і катарактальних хірургів у цьому питанні. В зв’язку з цим для скорочення терміну загального лікування та отримання кінцевого результату останнім часом застосовують біоптичний метод корекції астигматизму у три етапи, що у своїй роботі досліджувала А.А. Оздербаєва [8]. Цей метод виключає використання вакуумного кільця, тому ексимерлазерна корекція виконуються раніше. Але і при цьому методі проведення третього етапу коливається від 2 до 3 місяців, і немає обгрунтованих точних критеріїв щодо вирішення вибору часу для виконання операції.

\footnotetext{
(c) «Архів офтальмології України» / «Архив офтальмологии Украины» / «Archive Of Ukrainian Ophthalmology» («Arhìv oftal'mologiï Ukraïni»), 2018

(c) Видавець Заславський 0.Ю. / Издатель Заславский А.Ю. / Publisher Zaslavsky 0.Yu., 2018

Для кореспонденції: Завгородня Н.Г., Запорізький державний медичний університет, пр-т Маяковського, 26, м. Запоріжжя, 69035, Україна; e-mail: redact@i.ua For correspondence: N. Zavgorodnya, Zaporozhye State Medical University, Mayakovsky avenue, 26, Zaporizhzhia, 69035, Ukraine; e-mail: redact@i.ua
} 
Мета дослідження: оцінити ефективність хірургічного лікування катаракти на очах із рогівковим астигматизмом при факоемульсифікації катаракти 3 імплантацією торичної ІОЛ і використанням методу «Біоптика».

\section{Матеріали та метоАи}

Подано результати комплексного клініко-офтальмологічного обстеження 31 пацієнта (42 ока), прооперованих з приводу катаракти та супутнього рогівкового астигматизму від $0,5 \mathrm{D}$ до $3,75 \mathrm{D}$ за даними кератометрії, з яких у 8 випадках мала місце рефракційна заміна кришталика (РЗК). Серед обстежених було 17 чоловіків (55\%) та 14 жінок (45\%) віком від 20 до 79 років (середній вік $-53,5 \pm 2,14$ року). У 21 хворого мала місце незріла катаракта, у 13 - початкова, РЗК виконувалась на 8 очах. За типом астигматизму: прямий - у $71 \%$ (30 очей), обернений - у $12 \%$ (5 очей), з косою віссю - у $17 \%$ (7 очей) пацієнтів.

Передопераційно проводилася низка стандартних офтальмологічних обстежень (візометрія, авторефрактометрія, біомікроскопія, пряма офтальмоскопія, тонометрія, периметрія) та ультразвукове А-сканування, ендотеліальна мікроскопія, оптична біометрія, розрахунок торичної ІОЛ на апараті Verion ${ }^{\circledR}$ (Alcon), Carl Zeiss IOL Master, та рефракційна діагностика, а саме кератотопографія з пахіметрією, аберометрія та оптична когерентна томографія переднього відрізка ока при плануванні програми «Біоптика».

Супутньо була діагностована відкритокутова глаукома 1-го та 2-го ступеня на 4 очах, на 5 - первинна ендотеліальна дистрофія, міопія високого ступеня мала місце на 13 очах, вікова макулопатія - у 6 випадках.

Пацієнтам першої групи, що налічувала 17 хворих (22 ока), виконана факоемульсифікація катаракти (ФЕК) та імплантована торична ІОЛ (13 очей - монофокальна ІОЛ, на 8 очах - мультифокальна). Функціональний стан досліджуваних очей доопераційно: коригована гострота зору $-0,55 \pm 0,06$, некоригована $-0,16 \pm 0,02$. Показники астигматизму за даними авторефрактометра $-2,61 \pm 0,39 \mathrm{D}$, кератометрії $-1,38 \pm 0,13 \mathrm{D}$.

Другу групу становили 14 пацієнтів (20 очей), прооперованих за методом «Біоптика» (17 очей у три етапи, 3 ока у два етапи). Функціональний стан досліджуваних очей доопераційно: коригована гострота зору $-0,55 \pm 0,05$, некоригована $-0,13 \pm 0,03$. Показники астигматизму за даними авторефрактометра $2,80 \pm 0,37 \mathrm{D}$, кератометрії $-2,33 \pm 0,21 \mathrm{D}$.
Випадків інтра- та післяопераційних ускладнень не було.

Термін спостереження - від 1 місяця до 1 року післяопераційно.

Статистична обробка отриманих даних дослідження проводилась з розрахунком середньої арифметичної варіаційного ряду (М) та іï стандартної помилки (m). Для порівняння кількісних величин у парних рядах використовували t-критерій Стьюдента 3 попередньою оцінкою нормальності розподілу у варіаційному ряду. При відсутності нормального розподілу величин у досліджуваних вибірках застосовувався непараметричний критерій Манна - Уїнні. Відмінності вважалися вірогідними при $\mathrm{p}<0,05$. Систематизація матеріалу та подання результатів розрахунків проводилися з використанням статистичного пакета електронних програм Microsoft Excel 2013, Statistica ${ }^{\circledR}$ for Windows 10.0 (Stat Soft Inc.)

\section{Результати та обговорення}

Значне підвищення гостроти зору в результаті оперативного лікування відзначалось у всіх пацієнтів (табл. 1). Станом на перший місяць після операції: показники гостроти зору без корекції вірогідно підвищились у першій групі з 0,16 \pm 0,02 до 0,90 $\pm 0,03$ $(\mathrm{p}<0,01)$ та в другій групі - $30,13 \pm 0,03$ до 0,68 \pm 0,06, що теж було статистично значущим ( $<<0,01)$. Гострота зору з корекцією на цей період у першій групі зросла з 0,55 $\pm 0,06$ до 0,95 $\pm 0,02(\mathrm{p}<0,01)$, у другій -3 $0,55 \pm 0,05$ до $0,77 \pm 0,05(\mathrm{p}<0,01)$. Станом на 1 рік післяопераційно у 9 обстежених з кожної групи середній показник некоригованої гостроти зору становив 0,75 \pm 0,07 та 0,71 \pm 0,11 відповідно, що можна розцінювати як досягнення високого зору.

Згідно з табл. 1, гострота зору дещо вища у прооперованих з імплантацією торичної ІОЛ, ніж у хворих, прооперованих за методом «Біоптика». Але важливим $є$ сталість результату, а саме корекція астигматизму, зміни показників якого ми і розглянемо надалі (табл. 2.)

Відзначимо, що сила астигматизму, за даними авторефрактометра, після операції була на рівні $0,58 \pm 0,06 \mathrm{D}$ порівняно з вихідними показниками $2,61 \pm 0,39 \mathrm{D}$, що свідчить про зменшення астигматизму на 77,7\% (p < 0,01) у першій групі та на $75 \%(\mathrm{p}<0,01)$ у другій групі (до 2,80 \pm 0,37D та після $0,70 \pm 0,15 \mathrm{D})$. 3 огляду на вплив катаракти і кришталикового астигматизму, якщо порівняти вихідний рогівковий астигматизм, за даними кератометрії, та загальний астигма-

Таблиця 1. Зміна гостроти зору в результаті оперативного лікування, $\mathbf{M} \pm \mathbf{m}$

\begin{tabular}{|c|c|c|c|c|}
\hline \multirow{2}{*}{ Час обстеження } & \multicolumn{2}{|c|}{$\begin{array}{c}\text { Перша група (ФЕК + торична ІОЛ), } \\
\text { n = } 22\end{array}$} & \multicolumn{2}{|c|}{$\begin{array}{c}\text { Друга група (за методом «Біоптика») } \\
n=20\end{array}$} \\
\hline & Без корекції & 3 корекцією & Без корекції & 3 корекцією \\
\hline До операції & $0,16 \pm 0,02$ & $0,55 \pm 0,06$ & $0,13 \pm 0,03$ & $0,55 \pm 0,05$ \\
\hline $\begin{array}{l}\text { Через } 1 \text { місяць } \\
\text { післяопераційно }\end{array}$ & $0,90 \pm 0,03^{*}$ & $0,95 \pm 0,02^{*}$ & $0,68 \pm 0,06^{\star}$ & $0,77 \pm 0,05^{\star}$ \\
\hline $\begin{array}{l}\text { Через } 1 \text { рік післяопераційно } \\
\text { ( }=9 \text { з кожної групи) }\end{array}$ & $0,75 \pm 0,07^{\star}$ & $0,87 \pm 0,05^{\star}$ & $0,71 \pm 0,11^{*}$ & $0,81 \pm 0,09^{*}$ \\
\hline
\end{tabular}

Примітка: * - статистично вірогідна різниця з показником до операції (p < 0,01). 
Таблиця 2. Зміни показників рогівкового та загального астигматизму, $M \pm m$

\begin{tabular}{|l|c|c|c|}
\hline \multicolumn{1}{|c|}{ Група порівняння } & Час обстеження & $\begin{array}{c}\text { За даними } \\
\text { авторефрактометра, D }\end{array}$ & $\begin{array}{c}\text { За даними } \\
\text { кератометрії, D }\end{array}$ \\
\hline \multirow{3}{*}{$\begin{array}{l}\text { Перша група } \\
\text { (ФЕК + торична ІОЛ) }\end{array}$} & До операції $(n=22)$ & $2,61 \pm 0,39$ & $1,38 \pm 0,13$ \\
\cline { 2 - 4 } & Через 1 міс $(n=22)$ & $0,58 \pm 0,06^{\star}$ & $1,50 \pm 0,14^{\#}$ \\
\cline { 2 - 4 } & Через 1 рік $(n=9)$ & $0,69 \pm 0,18$ & $1,88 \pm 0,31$ \\
\hline \multirow{3}{*}{ Друга група («Біоптика») } & До операції $(n=20)$ & $2,80 \pm 0,37$ & $2,33 \pm 0,21$ \\
\cline { 2 - 4 } & Через 1 міс $(n=20)$ & $0,70 \pm 0,15^{\star \wedge}$ & $1,00 \pm 0,25^{\star \wedge}$ \\
\cline { 2 - 4 } & Через 1 рік $(n=9)$ & $0,72 \pm 0,14$ & $0,94 \pm 0,16$ \\
\hline
\end{tabular}

Примітки: * - статистично вірогідна різниця з показником до операції (p < 0,01); * — різниця показника статистично невірогідна порівняно з доопераційними даними (p > 0,3); ^ — різниця даних з групою порівняння вірогідно значима $(p<0,01)$.

тизм після операції, то ми бачимо зменшення цифр на $57,9 \%$ (з 1,38 $\pm 0,13 \mathrm{D}$ до $0,58 \pm 0,06 \mathrm{D})$ у першій групі та на $69,9 \%$ (з 2,33 $\pm 0,21 \mathrm{D}$ до $0,70 \pm 0,15 \mathrm{D})$, що в кожному випадку можна вважати статистично вірогідним.

При оцінюванні змін рогівкового астигматизму за даними кератометрії виявлено, що в першій групі показники стали дещо вищими: $31,38 \pm 0,13 \mathrm{D}$ до $1,5 \pm 0,14 \mathrm{D}$ ( $>>0,3)$, але вірогідно не змінились, що можна пояснити виникненням індукованого астигматизму. Якщо розглядати окремо, то в 6 випадках показники залишились на тому самому рівні, у 8 випадках астигматизм збільшився на $0,25 \mathrm{D}$, а в 6 навіть зменшився на $0,25 \mathrm{D}$, в одному - на $0,5 \mathrm{D}$, що є добрим результатом. Однак навіть ці зміни в ту чи іншу сторону впливають на прогнозованість залишкового астигматизму.

У пацієнтів, прооперованих за методом «Біоптика» із застосуванням кераторефракційного втручання, показники астигматизму за даними кератометрії вірогідно зменшились з 2,33 $\pm 0,21 \mathrm{D}$ до $1,00 \pm 0,25 \mathrm{D}(\mathrm{p}<0,01)$.

При порівнянні даних загального астигматизму через 1 рік після операції між обома групами різниця була вірогідно незначущою ( $>$ > 0,05), тому можна зробити висновок про ефективність кожного з методів оперативного лікування.

Головним критерієм, як ми зазначали вище, є сталість показників загального астигматизму. Рефракційні показники пацієнтів, прооперованих з імплантацією торичної ІОЛ, мали приріст загального астигматизму, згідно з табл. 2, з 0,58 $\pm 0,06 \mathrm{D}$ до 0,69 \pm 0,18D, що відповідає $15,9 \%$, натомість у другій групі приріст становив лише $2,8 \%$ (з $0,7 \pm 0,15 \mathrm{D}$ до 0,72 $\pm 0,14 \mathrm{D})$. Такі показника свідчать, що віддалені результати більш стабільні при застосуванні програми «Біоптика».

\section{ВИсновки}

Підсумовуючи вищевикладене та проаналізувавши дані рефракційних показників оперативного лікування хворих на катаракту з супутнім рогівковим астигматизмом, можна зробити такі висновки:

1. Факоемульсифікація катаракти з імплантацією торичних ІОЛ, як і використання програми «Біоптика», дозволяє досягти високої гостроти зору на очах із супутнім рогівковим астигматизмом.

2. Зменшення загального астигматизму досягнуто в усіх прооперованих хворих.
3. Віддалені рефракційні результати корекції астигматизму більш стабільні при застосуванні програми «Біоптика».

4. Необхідні спостереження за більш віддаленими результатами рефракційних показників у пацієнтів i розробка шляхів удосконалення оперативного лікування катаракти на очах із рогівковим астигматизмом.

Конфлікт інтересів. Автори заявляють про відсутність конфлікту інтересів при підготовці даної статті.

\section{Список Аітератури}

1. Хрипун К.В. Хирургическая коррекция астигматизма во время и после экстракции катаракты: Дис... канд. мед. наук: 14.01.07/ Хрипун К.B. - M., 2016. - 114 c.

2. Leaming D. Practice styles and preferences of ASCRS members - 2003 survey / D. Leaming // J. Cataract Refract. Surg. 2004. - Vol. 30(4). - P. 892-900.

3. Wallace R.B. Refractive cataract surgery and multifocal IOLs / R.B. Wallace. - Thorofare, NJ: SLACK Incorporated, 2000. - 23 p.

4. Новая эра в лечении астигматизма: методики и технологии, разрушающие старые концепции / У.Э. Хилл, Д.Т. Холлэдей, Д. Дэвидсон, С.В. Скопер // Новое в офтальмологии. 2016. - № 1. - C. 30-36.

5. Мельник В.О. Досвід імплантації інтраокулярних линз AcrySof IQ Toric при факоемульсифікації катаракт у хворих з високим ступенем астигматизму / В.О. Мельник // «Філатовські читання»: наук.-практ. конференція офтальмологів з міжнародною участю, 24-25 трав. 2012 р.: матеріали. - Одеса, 2012. - C. 74.

6. Федяшев Г.А. Оценка ротационной стабильности торических линз AcrySof Toric после факоэмульсификации возрастной катаракты / Г.А. Федяшев, В.В. Егоров, А.В. Егорова // Современные технологии катарактальной и рефракционной хирургии: ХІ науч.-практ. конф: тезисы докл. - М., 2010. - С. 210-212.

7. Бубнова И.А. Возможности коррекции астигматизма методом LASIK в хирургии катаракты: Дис... канд. мед. наук: спеи. 14.00.08 «Глазные болезни» / Бубнова И.А. - М., 2006. - 122 c.

8. Оздербаева А.А. Биоптический метод коррекции роговичного астигматизма у пациентов с катарактой и миопией: автореф. Дис... канд. мед. наук: 14.01 .07 «ллазные болезни» / Оздербаева А.А. - М., 2012. - 24 c.

Отримано 04.09.2018 
Завгородняя Н.Г., Новикова В.Ю.

Запорожский государственный медицинский университет МЗ Украины, г. Запорожье, Украина

\section{Результаты коррекции роговичного астигматизма при факоэмульсификации катаракты с имплантацией торической интраокулярной Аинзы и по программе «Биоптика"}

Резюме. Для оценки эффективности хирургического лечения катаракты на глазах с роговичным астигматизмом при факоэмульсификации катаракты с имплантацией торической интраокулярной линзы (ИОЛ) и по методу «Биоптика» обследован 31 больной (42 глаза). Выявлено, что имплантация торических ИОЛ, как и использование программы «Биопти- ка», позволяет получить высокую остроту зрения на глазах с астигматизмом. Достоверное уменьшение общего астигматизма имело место у всех больных; отдаленные результаты более стабильны при применении программы «Биоптика».

Ключевые слова: торические ИОЛ; «Биоптика»; коррекция астигматизма.

N.G. Zavgorodnya, V.Yu. Novikova

Zaporizhzhia State Medical University of the Ministry of Health of Ukraine, Zaporizhzhia, Ukraine

\section{Results of corneal astigmatism correction in phacoemulsification of cataract with the implantation of toric intraocular lenses and using the Bioptics program}

Abstract. Background. One of the most urgent tasks in modern cataract surgery is to obtain the most predictable and accurate refractive result. At the present stage, one of the proposed methods for astigmatism correction is the use of toric intraocular lenses (IOLs). To correct these refractive disorders, various methods of refractive surgery are proposed. The purpose was to evaluate the effectiveness of surgical treatment of cataract in the eyes with corneal astigmatism during phacoemulsification of cataract with implantation of toric IOL and using the Bioptics method. Materials and methods. We have examined 31 patients (42 eyes) aged 20 to 79 years with cataract and corneal astigmatism from 0.5 to $3.75 \mathrm{D}$ according to keratometry, operated for cataract. Besides the general ophthalmological examination, all patients were examined with A-scan, endothelial microscopy, optical biometry, calculation of toric IOL. Patients in the first group $(\mathrm{n}=17 ; 22$ eyes) underwent cataract phacoemulsification and implantation of toric IOL. The second group consisted of 14 patients ( 20 eyes) operated using the Bioptics method. Results. Results showed a significant increase in visual acuity as a result of surgical treatment in all patients. Also, the astigmatism according to autorefractometry after the operation was at the level of $0.58 \pm 0.06 \mathrm{D}$, in contrast to the baseline $2.61 \pm 0.39 \mathrm{D}$, which indicates a decrease in astigmatism in group I by $77.7 \%(\mathrm{p}<0.01)$ and a decrease by $75 \%(\mathrm{p}<0.01)$ in group II (before $-2.80 \pm 0.37 \mathrm{D}$ and after $-0.70 \pm 0.15 \mathrm{D}$ ). The index of total astigmatism in patients who were implanted with toric IOL increased for a year by $15.9 \%$, from $0.58 \pm 0.06 \mathrm{D}$ to $0.69 \pm 0.18$ $\mathrm{D}$, and in the second group - by only $2.8 \%$ (from $0.70 \pm 0.15 \mathrm{D}$ to $0.72 \pm 0.14$ D). Conclusions. Phacoemulsification of cataract with the implantation of toric IOL, as well as use of the Bioptics program allows achieving high visual acuity in the eyes with concomitant corneal astigmatism. Reduction of total astigmatism is achieved in all operated patients. The remote refractive results of astigmatism correction are more stable when using the Bioptics program. It is necessary to monitor the more distant results of refractive indexes in these patients and to develop the ways to improve the surgical treatment of cataract in the eyes with corneal astigmatism.

Keywords: toric intraocular lenses; Bioptics; astigmatism correction 